\title{
College Students' Learning Style in Basic Listening Course at English Department UNP Padang
}

\author{
Aryuliva Adnan ${ }^{1 *}$, Leni Marlina ${ }^{2}$, and Amalya Shawfani ${ }^{3}$ \\ ${ }^{1 *}$ Universitas Negeri Padang, Padang and Indonesia, $\triangle$ (e-mail), aryuliva.adnan@yahoo.co.id \\ ${ }^{2}$ Universitas Negeri Padang, Padang and Indonesia, $\triangle$ (e-mail), lenimarlina.11@gmail.com \\ ${ }^{3}$ Universitas Negeri Padang, Padang and Indonesia, $\triangle$ (e-mail), amaliashawfani@gmail.com
}

\begin{abstract}
Most students at English Department of UNP experience difficulties in learning Listening courses. Besides it is very rare for the students to realize their learning strategies which are suitable with their learning style. As a result, every semester many students have problems with their listening comprehension and listening achievement. On the other hand, many students pass this course poorly. That is why a research about students' learning style particularly in Basic Listening course at English department UNP Padang is needed to be conducted. The purpose of this research was to describe learning style of students particularly in Basic Listening course. This research used descriptive method and the population of the research were all students who had already taken Basic Listening course by 2019. The sample of this research was chosen by using purposive random sampling technique. The data were collected by using questionnaire. This result of this research showed the students had various learning styles and mostly their learning styles were dominated by visual style. Further research to see the correlation between students' learning style and their learning comprehension were suggested.
\end{abstract}

Keywords: learning style, basic listening

\section{INTRODUCTION}

Learning is a process in life that requires a long time to obtain and perceive by all people in the world. Learning is very important for each person in order to obtain their education much better in their life. Unfortunately, for the process of learning itself, many lecturers do not pay attention with that (Abidin, Rezaee, Abdullah, and Singh, 2011, p. 143). The students get frustrated by the lecturers because they do more have attention for what is being taught compared with the way they present the materials. Meanwhile, many specialists say that students enjoy the variety of learning style. It is very true because of the fact that learners enjoy the class much if the lecturers pay attention to the way they present the material compared with the materials that the students obtain in the class. Unfortunately, learning style is one of the components in the class that is left by the lecturers itself.

Dunn (in Abidin, Rezaee, Abdullah, and Singh, 2011, p. 143) stated that learning style has much great impact on the students' achievement compared with the materials that are presented by the lecturers in the class. It is believed that the lecturers have to pay attention with the students' learning style or the way the lecturers give the material to the students due to the fact that each student has different biological and psychological sides. Pask (in Abidin, Rezaee, Abdullah, and Singh, 2011, p. 143) stated that more than half of people have learning style that is biologically connected with them. That is the reason why the students have to be paid attention about their learning styles by the lecturers in order not to make them in the frustration cycle and it will result toward the better result of the learning process itself.

Learning style is the way the students understand, have interaction, and have response toward the environment of learning based on the cognitive, affective, and psychological traits (Gantasala and Gantasala, 2009, p. 170). Learning style is also same with individual learning methods. The experts see that as learning tactics, strategies or styles, approaches to learning, ways of thinking, and the others (Malcik and Miklosikova, 2017, p. 211). Those kinds of that are seen as the specific way of the students to achieve their certain result toward the lesson. It should be the lecturers' responsibility to know the different way of the students perceive the lesson in order to make the lecturers aware and sensitive toward the classroom differences brought by the students itself.

\section{Learning Style}

Learning style is the way the students understand, have interaction, and have response toward the environment of learning based on the cognitive, affective, and psychological traits (Gantasala and Gantasala, 2009, p. 170). Basically, the students learn based on the way they learn individually. For example, for the students who are visual, they tend to understand the lesson if they study with pictures or anything that they can see or they can 
imagine that based on their visual capability. If the students are audio, they tend to perceive the lesson with audio or based on their listening capability. If the students are kinaesthetic, they tend to understand the lesson if they do the practice.

Learning style has three models (Dunn and Dunn in Gantasala and Gantasala, 2009, p. 173-174). They stated that this model is VAK which is based on three parts of sensory receivers such as Visual, Auditory, and Kinaesthetic.

Table 1. Types of Learning Style

\begin{tabular}{|rl|}
\hline \multicolumn{2}{|c|}{ Dunn and Dunn's Learning Style Theory } \\
\hline Visual: \\
1. & The thought is easily distracted. \\
2. & Observer \\
3. & An organised person \\
4. & Have good spelling \\
5. & Have strong memory by having images in mind \\
\hline Auditory: \\
1. & Have difficulty with verbal instructions \\
2. & Strong on first impressions \\
3. & Prefer drawing \\
4. & Having good time by using colours \\
\hline Kinaesthetic: \\
1. & Express the emotions physically \\
2. & Holding or playing pencil or foot \\
3. & Do not like reading \\
4. & Spelling is difficult for them \\
\hline
\end{tabular}

From Dunn and Dunn in Gantasala and Gantasala, 2009, p. $173-174$

Visual learners are the learners or students that study through vision. They tend to see and observe while studying. It is going to make them have better understanding toward the lesson compared not to see the object. "The strongest part of the visual learners is they have better memory through images." (Dunn and Dunn in Gantasala and Gantasala, 2009, p. 173-174). So, when the lecturers explain through images or videos, it is going to make them easy in studying.

Auditory learners tend to hear or listen when studying. The students who have this learning style have better understanding if the lecturers play an audio or something like that, but the students who have auditory learning style, if they hear or listen another sound, they are easily get distracted by that and do no focus toward the lesson itself.

Kinaesthetic learners tend to do or move or grab something. For example, when studying, the students tap pencils or foot with objects and they enjoy handling objects. They cannot stay still when studying because they do mind what they have done rather than have visual or audio. So, they will have better understanding if they do or grab something while studying.

\section{METHODS}

This research aimed to analyse the learning style of English students in English Department, especially for Education students and Literature students. In this research, the researcher uses descriptive research.

For the population of the research, there are 8 classes in English Department. They are 5 classes of Education students and 3 classes of Literature students. From this population, the researcher will take 1 each of the two types of classes. They are one class from ELEP (English Language Education Programme) and one class from ELP (English Language Programme). The type of the sampling in this research will use random sampling. Random sampling is sampling that can make all students have equal right to be included in the sample. Based on this type of sampling, the researcher can know toward the amount of students who mostly choose one type of their learning style.

There is one kind of questionnaire to be used in this research. That is ILS adapted from University of Bradford. In ILS questionnaire, there are eight types of learning styles. Questionnaire is very appropriate to be used due to the effectiveness to take the data related with the analysis of learning style of students in basic listening skill.

In terms of collecting the data, the researcher gave the questionnaire that the students fill based on the type of their learning style in basic listening skill. The college students in English Department filled that based on the time provided by the researcher. Then, if they had finished in filling both of the questionnaires, they gathered it toward the researcher. After that, the researcher counted the data at home.

Questionnaire is an instrument that used to collect the information, structured, numerical data, can be taken even if there is no researcher, and comparatively straightforward to analyze (Wilson and McLean in Cohen, Manion, and Morrison, 2007, p. 317). Specifically, the questionnaire is used in this research is rating scales. This kind of questionnaire is very useful to be used because it builds in a degree of sensitivity and differentiation of responses.

In analysing the data, the researcher differenciate the questionnaires based on their types. The researcher analyse one by one of the questionnaires using Microsoft Excel. For ILS Questionnaire, the researcher count how many students choose their particular learning style for each type of learning style, then the researcher make the percentage based on the data. $।$

\section{FINDINGS AND DISCUSSION}

In class 1, mostly the students have sensing learning style $(78,13 \%$ ) as their learning style in basic listening skill. For the second choice, the students choose visual $(68,75 \%)$. For the third choice, the students choose active $(68 \%)$. Lastly, the students choose sequential $(53,13 \%)$. 

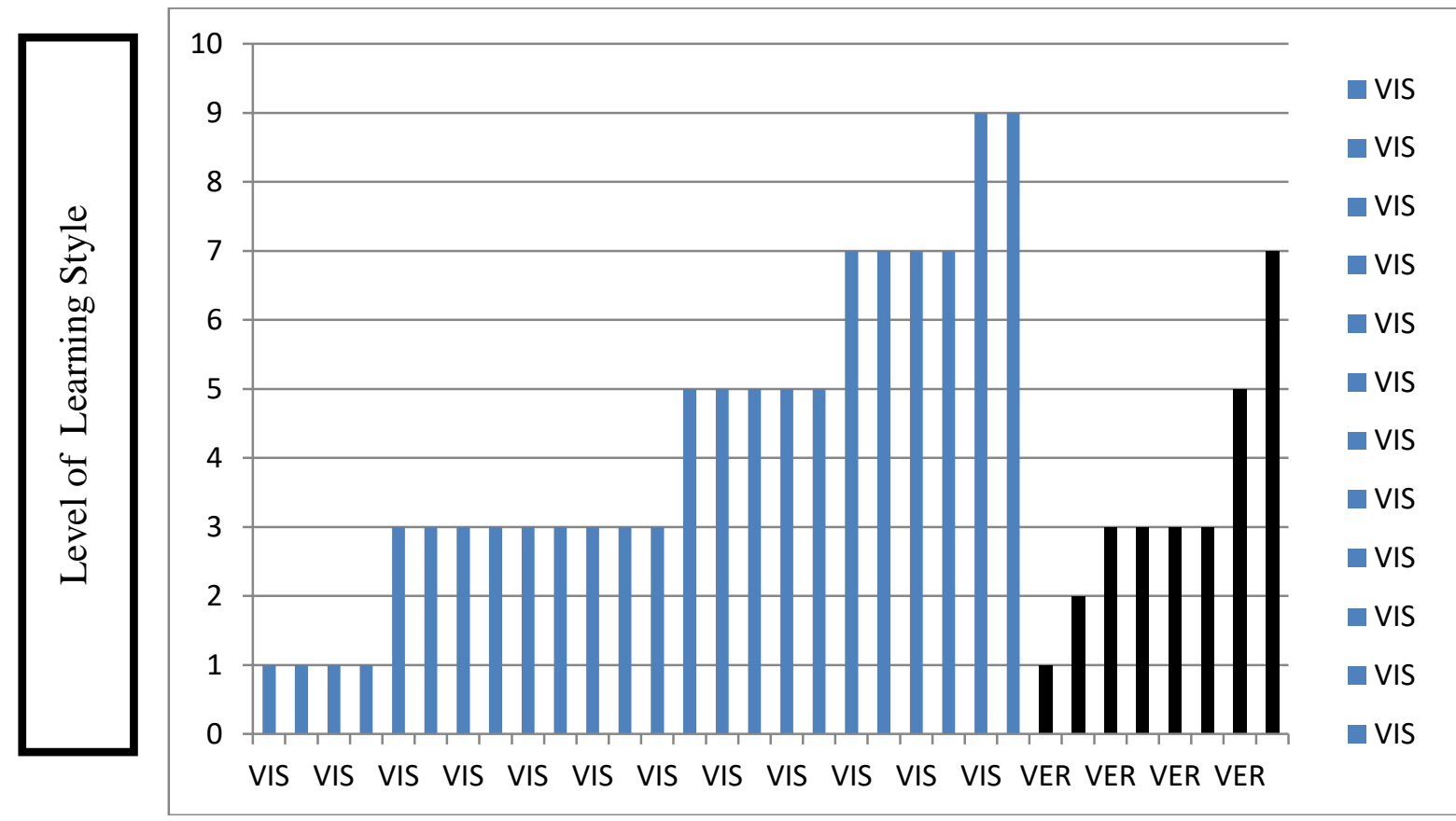

Figure 1. Individual Learning Styles Preferences

Data 1: The chart describes visual or verbal learning style

*VIS=Visual

VER=Verbal
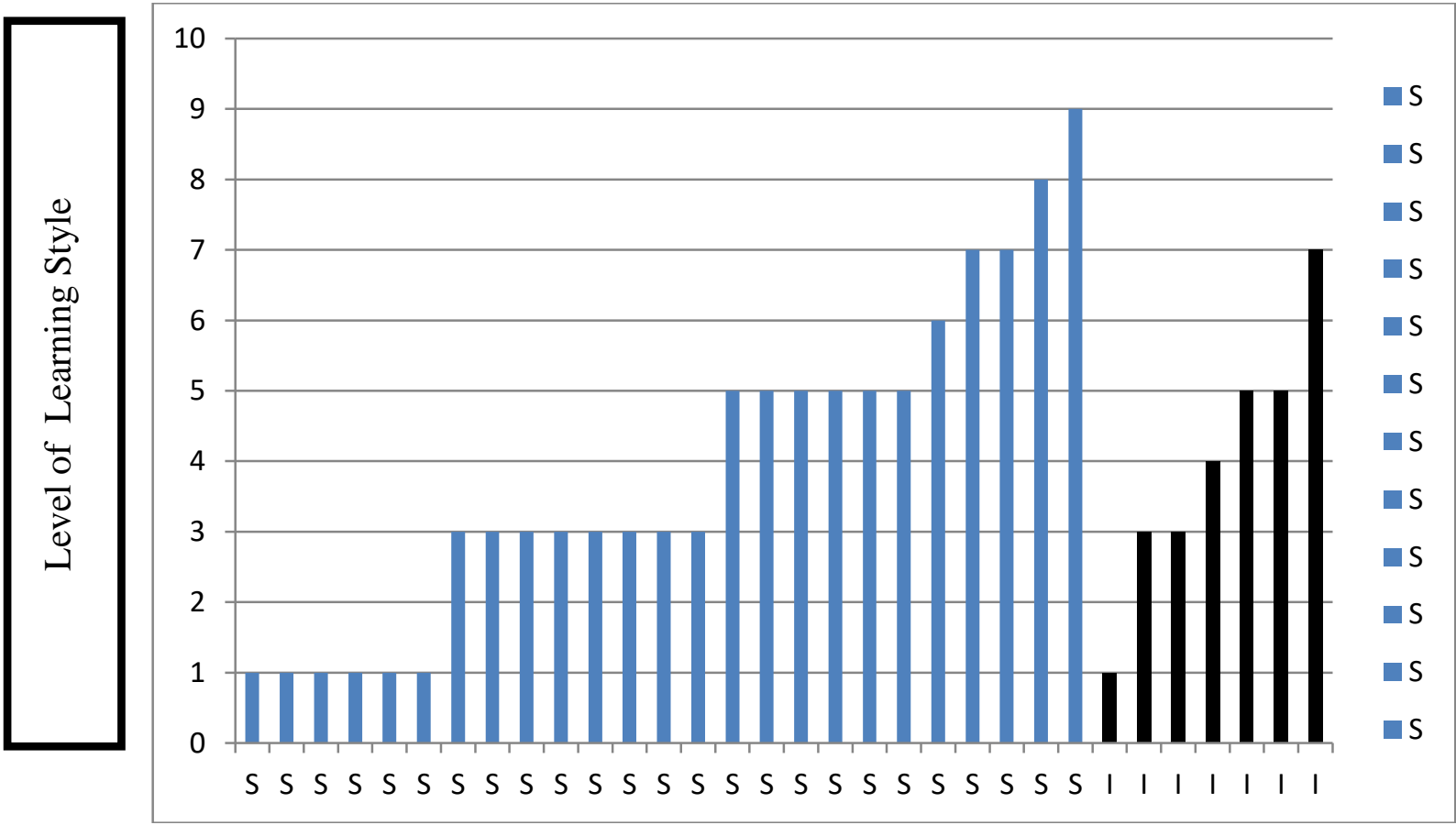

Figure 2. Individual Learning Styles Preferences

Data 2: The chart describes sensing or intuitive learning style

$* \mathrm{~S}=$ Sensing

I=Intuitive 


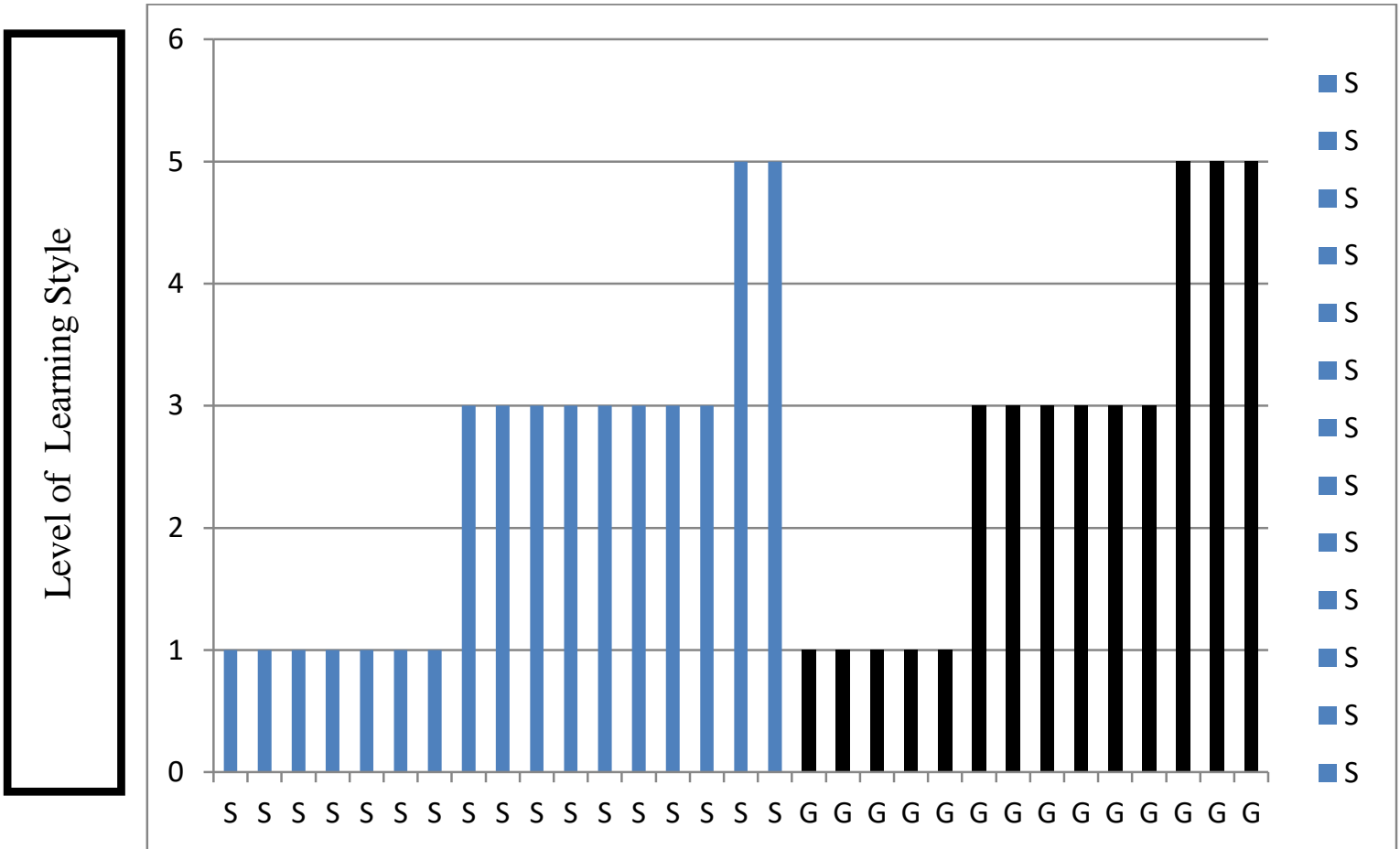

Figure 3. Individual Learning Styles Preferences

Data 3: The chart describes sequential or global learning style

$* \mathrm{~S}=$ Sequential

$\mathrm{G}=\mathrm{Global}$
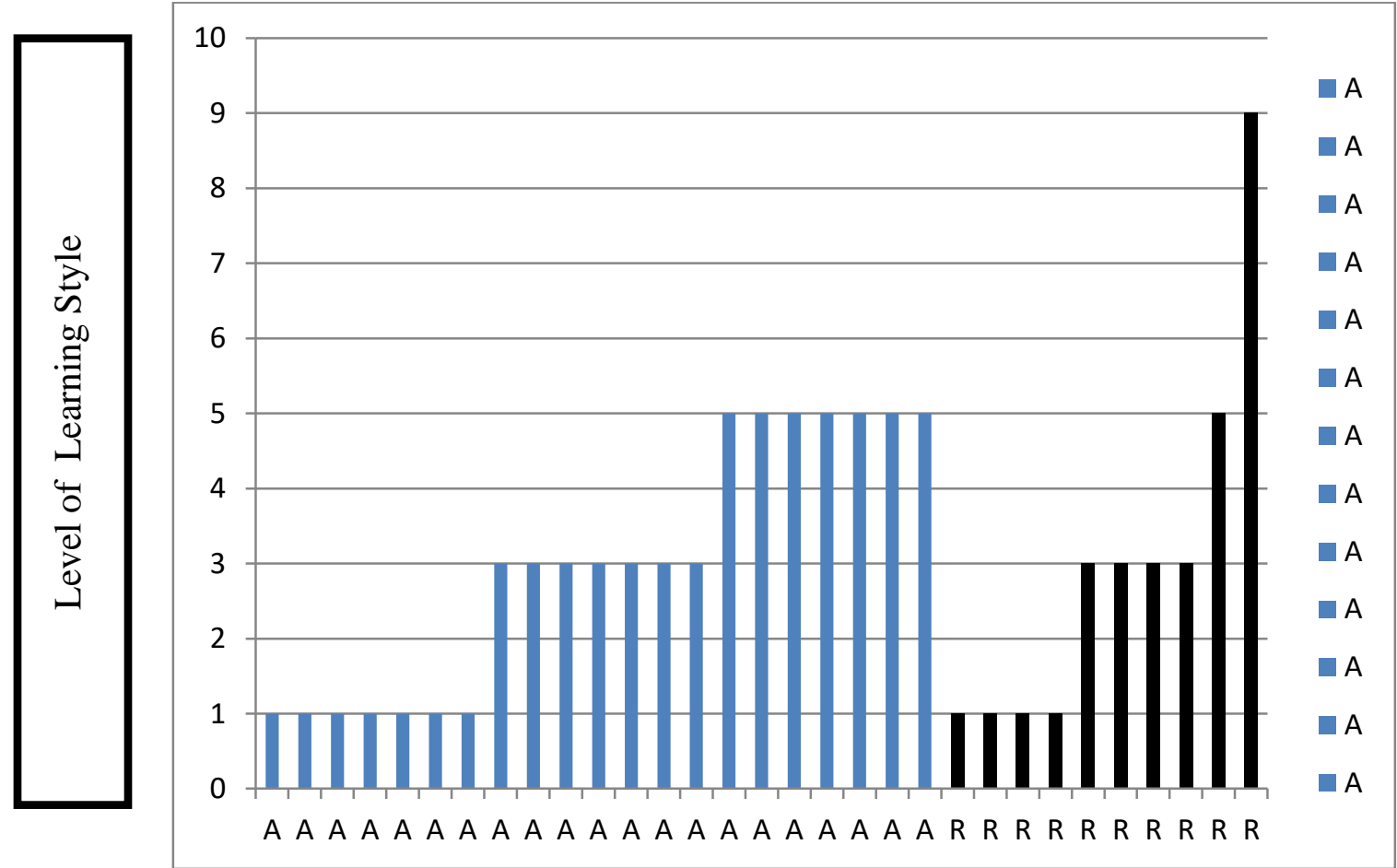

Figure 4. Individual Learning Styles Preferences

Data 4: The chart describes active or reflector learning style

$* \mathrm{~A}=$ Active

$\mathrm{R}=$ Reflective 
In class 2 , mostly the students have sensing learning style (79\%) as their learning style in basic listening skill. For the second choice, the students choose active $(76 \%)$. For the third choice, the students choose sequential (59\%). Lastly, the students choose visual $(35,2 \%)$.
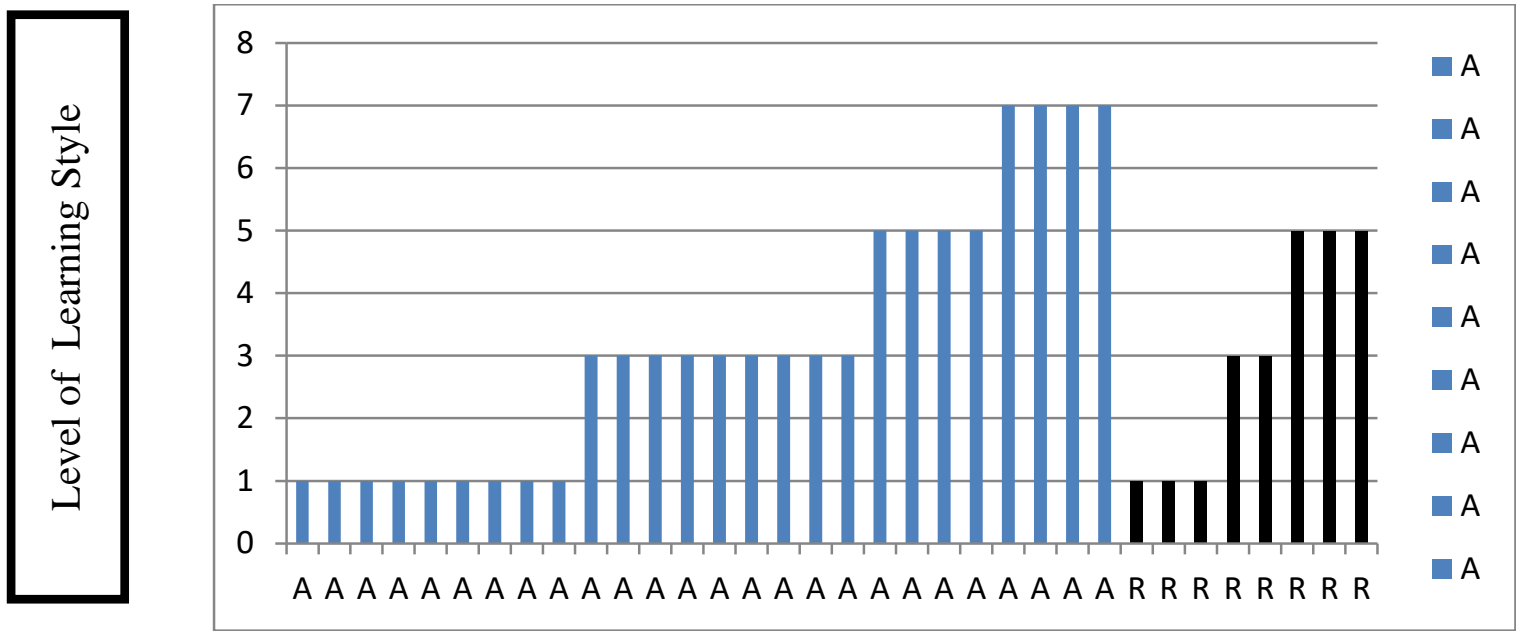

Figure 5. Individual Learning Styles Preferences

Data 5: The chart describes active or reflector learning style

$* \mathrm{~A}=$ Active

$\mathrm{R}=$ Reflective
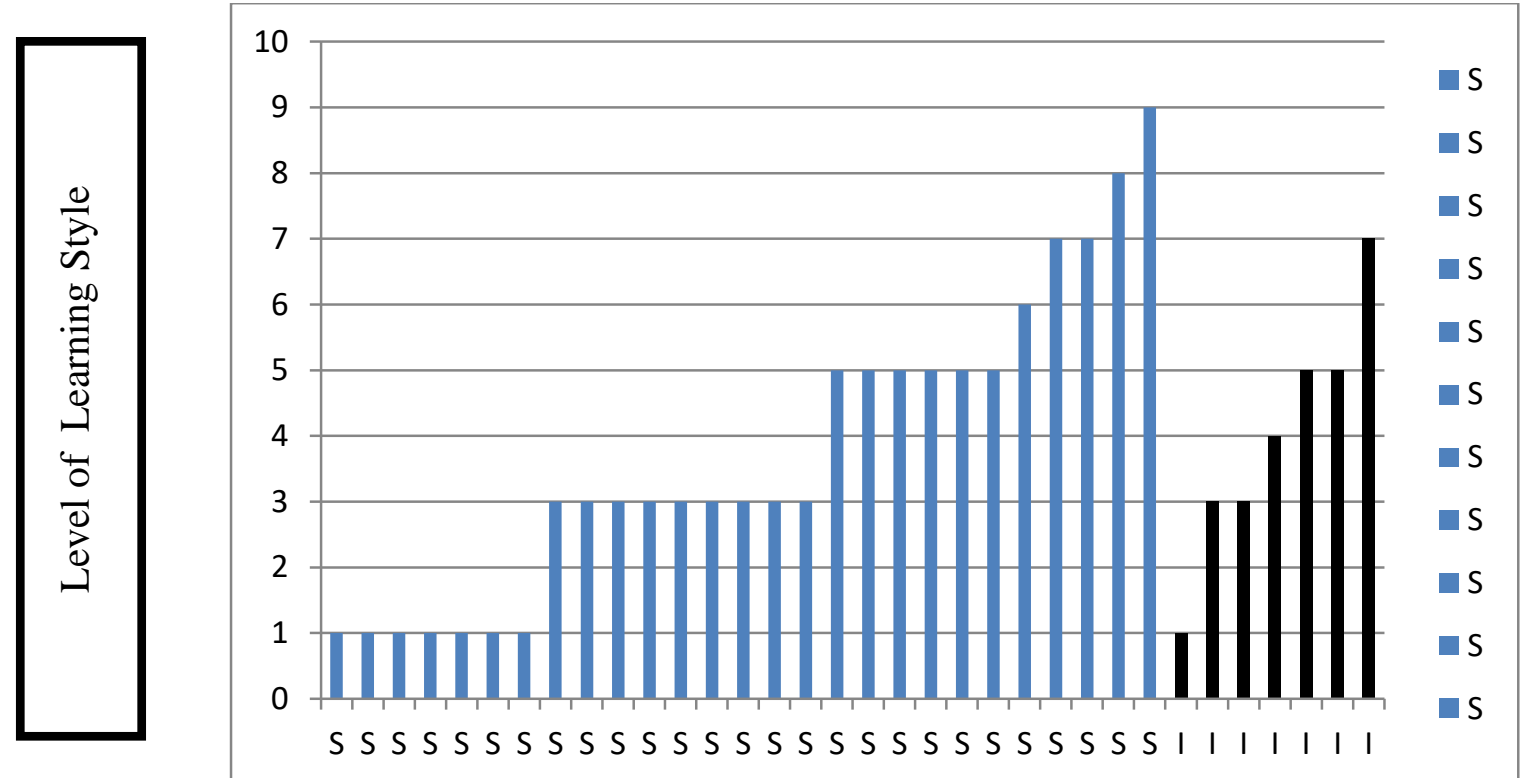

Figure 6. Individual Learning Styles Preferences

Data 6: The chart describes sensing or intuitive learning style

*S=Sensing

I=Intuitive 

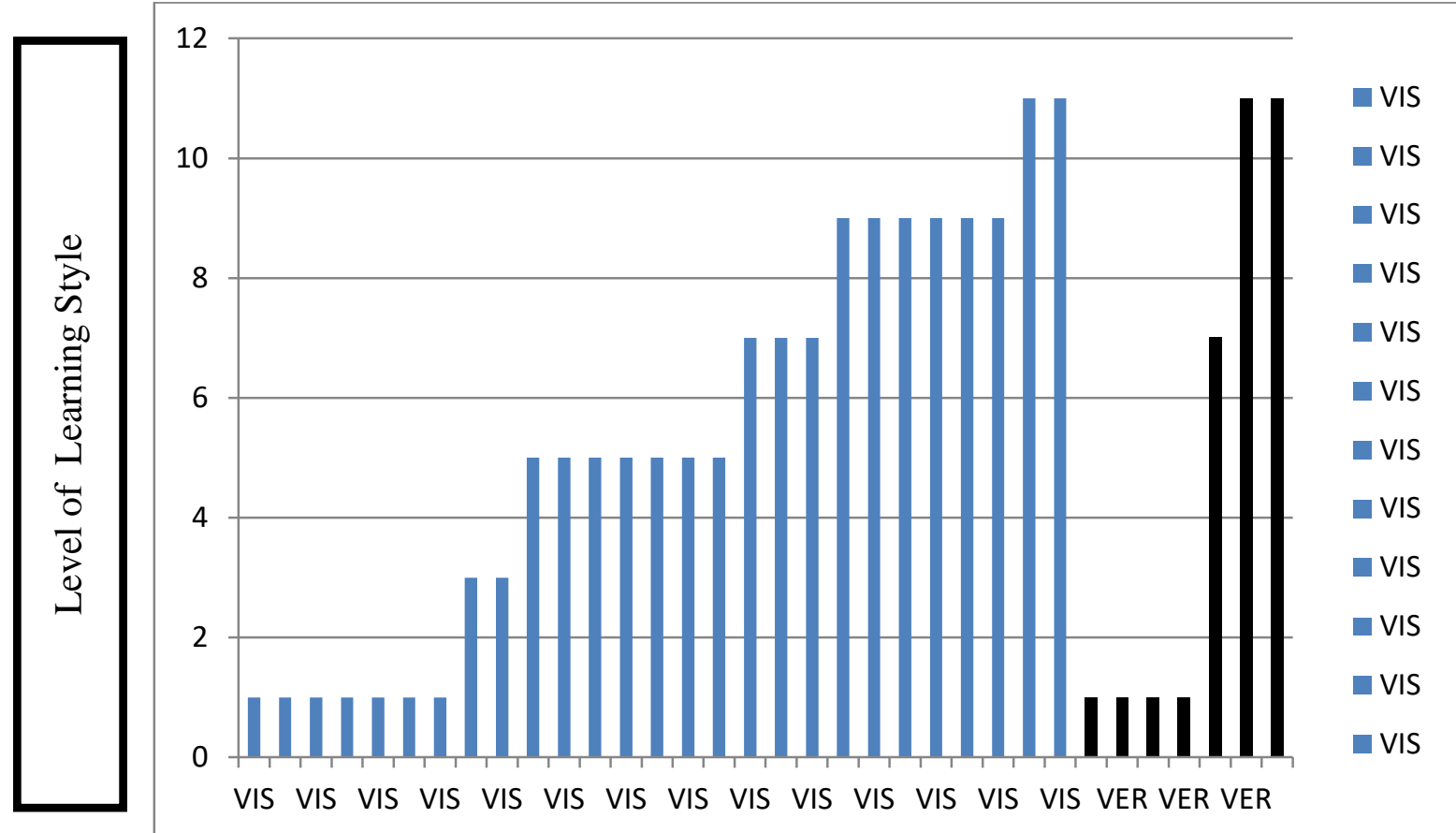

Figure 7. Individual Learning Styles Preferences

Data 7: The chart describes visual or verbal learning style

$* \mathrm{~V}=\mathrm{Visual}$

$\mathrm{VR}=$ Verbal
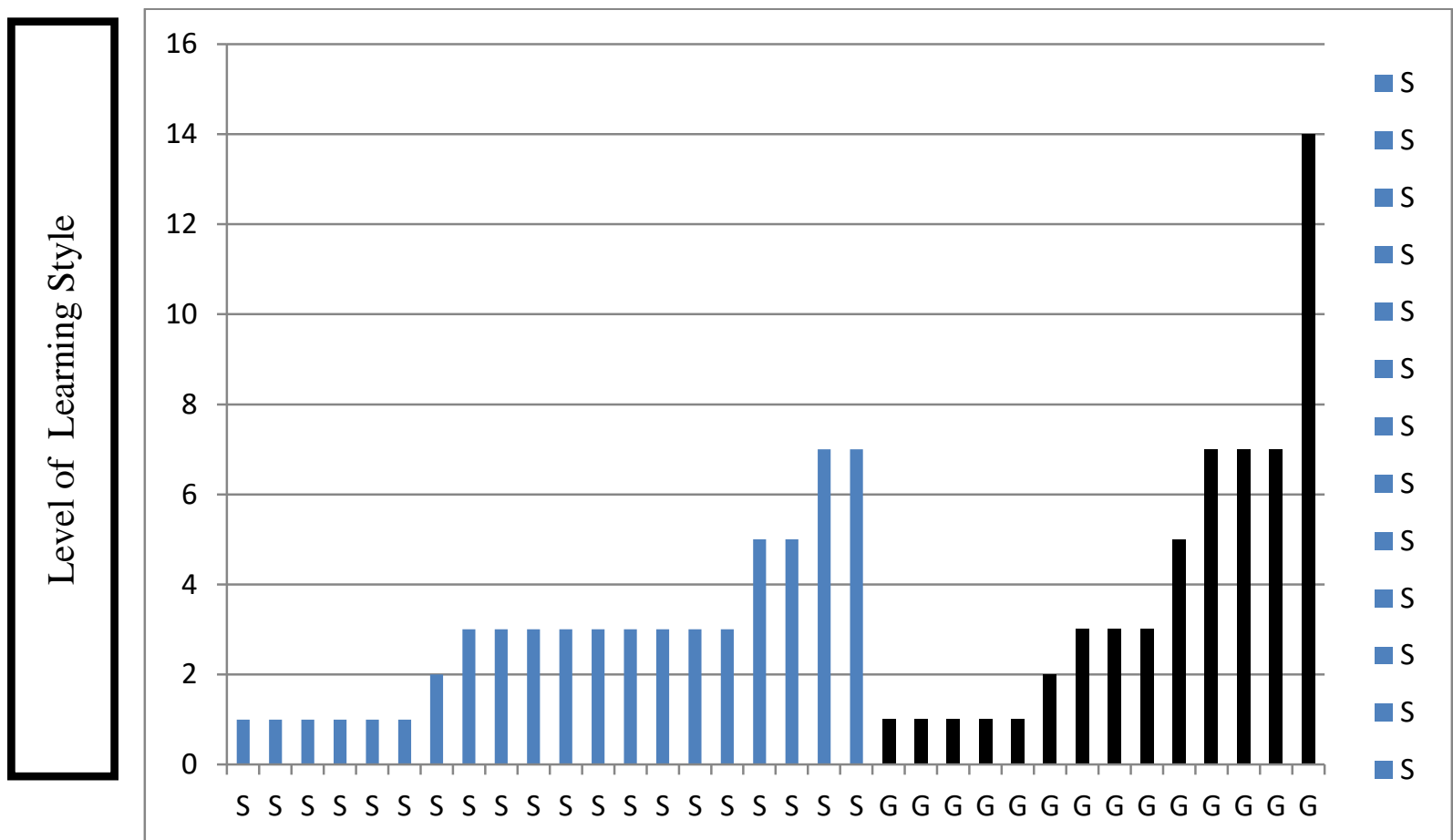

Figure 8. Individual Learning Styles Preferences

Data 8: The chart describes sequential or global learning style

*S=Sequential

$\mathrm{G}=$ Global 
Based on the data above, it can be seen that many students choose sensing as their learning style which means they tend to learn based on facts and not based on opinion.

\section{DISCUSSION}

Listening is one of the most important skill that has to be learned by all students when they study English and one of the first skill that students have to perceive and pass is the basic listening skill. Basic listening is the listening class that filled with the knowledge of basic in language, such as vocabulary, grammar, pronunciation, and other language materials (Hadijah, 2016, p. 71). Also, in basic listening, the students learn two varieties of

In the ILS questionnaire, sensing learning style is the highest preferred learning style in the class. Sensing is the learning style that the students tend to learn through senses which make they prefer to think present and future and they tend to learn based on the facts instead of theories. They prefer to be guided by the teachers (Felder and Oxford in 1993 and 2001 in Awla, 2014). In addition, according to the Felder in 1996 in websites University of Waterloo stated that the students who have sensing learning style prefer to use proven procedures and they tend to do something in action. Also, the students who have visual of VARK questionnaire is the highest result of learning style chosen by the students. Based on the several previous researches, visual was also the highest chosen learning style by the students. First, the research that was done by Jamulia (2018). He found visual was the highest chosen learning style by the first year students of academic year 2012/2013 at IAIN Ternate seen from the mean data of the research $(42,2)$. For the statement in the questionnaire, mostly the students had high preferences in statement number 2 and 3 . The statement number stated that "When I read instructions, I remember them better" and statement 3 "I understand better when I read instructions".

Oxford (2003) in Jamulia (2018) stated that visual students are the students who tend to read or observe things while studying. Lectures, conversations, and the others media without visual backup can be very confusing for the visual students. He also gave suggestions how to behave with the visual students. Firstly, providing the instructions while studying since they learn better by reading. Second, teaching the students through power point or writing summary and concept on the white board. Lastly, providing the photocopies of material while studying since they learn better while reading compared to listening the lectures.

Second, the research that was done by Ihsan and Diem (1997). They stated that visual was the learning style mostly preferred by 156 English students at the University of Sriwijaya, Palembang seen from the average score $(21,4)$ supported by metacognitive and affective that students use as their strategies in learning.

Lastly, the research that was done by Tabatabaei and Mashayekhi (2013). They stated in their result that mostly the Iranian pre-university EFL students chose knowledge. They are linguistics and non-linguistic knowledge (Graham, 2006, p. 2).

Based on the explanation of the previous paragraph, there are two kinds of knowledge of the basic listening skill that has to be perceived. First, the knowledge in linguistics term, such as syntax, lexis, and the others that learned by the second class. In the second class, the students tend to study with sensing learning style which means they tend to learn based on facts insted of opinion. Second, the knowledge of non-linguistic term, such as topic, context, and general knowledge that learned by first class. In the first class, they tend to learn based on sensing also.

visual as their learning style compared to auditory, tactile, and kinaesthetic.

\section{CONCLUSION}

To conclude, it is ver clear that learning style is the way the students do while they are studying. If it is not found appropriate, it can make them are lazy to study and harm for them to understand the lesson. The are general kind of learning styles, such as visual, audio, and kinaesthetic. When listening especially, the students tend to study based on the learning style and in this research, mostly the students tend to choose sensing and visual as their learning style.

\section{ACKNOWLEDGMENT}

This article is one of the external parts of University Superior Research (Basic) entitled "College Students' Learning Style in Basic Listening Course at English Department UNP Padang". The writer says thank you to the LP2M Universitas Negeri Padang who has funded this research activity.

\section{REFERENCES}

[1] Abidin, Rezaee, Abdullah, and Singh (2011). Learning Styles and Overall Academic Achievement in a Specific Educational System, Vol. 1, No.10, International Journal of Humanities and Social Science, p. 143-152.

[2] Awla (2014). Learning Styles and Their Relation to Teaching Styles, Vol. 2, No. 3, International Journal of Language and Linguistics, p. 241-245.

[3] Gantasala\&Gantasala (2009). Influence of Learning Styles, Vol. 16, No.9, The International Journal of Learning, p. 169-186.

[4] Ihsan and Diem (1997). The Learning Styles and Language Learning Strategies of the EFL Students at Tertiary Level, Vol. 4, The Journal of Education, p. 319-332.

[5] Jamulia (2018). Identifying Students' Learning Style Preferences at IAIN Ternate, Vol. 10, No. 2, International Journal of Education, p. 121-129.

[6] Lehmann \&Ifenthaler (2012). Influence of Students' Learning Styles on the Effectiveness of 
Instructional Interventions, International Conference on Cognition and Exploratory Learning in Digital Age (CELDA), p. 180-188.

[7] Malcik\&Miklosikova (2017). Learning Styles of Students as a Factor Affecting Pedagogical Activities of a University Teacher, Vol. 12, No. 2, International Journal of English Teaching, p. 210218.

[8] Tabatabaei and Mashayekhi (2013). The Relationship between EFL Learners' Learning Styles and Their L2 Achievement, Vol. 70, Procedia, p. 245-253.

[9] Wilson, Mary (2012). Students' Learning Style Preferences and Teachers' Instructional Strategies: Correlations Between Matched Styles and Academic Achievement, Vol. 22, No. 1, SRATE Journal, p. 36-44. 